\title{
The Impact of Policy on Somali Refugee Women in Canada
}

\author{
Denise L. Spitzer
}

\section{Abstract}

This paper explores the ways in which government policy and public discourse have operated to enhance and maintain the liminal status of Somali women refugees in Canada, and the ways in which Somali Canadian women have resisted these efforts in order to create meaning and a place for themselves and their families in North America. The policies and practices that obliged many Somali women to wait three to five years to apply for permanent residency status, Eurocentric definitions of the family that constrain family unification strategies, and economic marginalization due to lack of recognition of foreign credentials have had cumulative adverse effects on the health and well-being of Somali women in Canada.

\section{Résumé}

L'article se penche, d'une part, sur la manière dont les politiques gouvernementales et le discours public ont contribué à rehausser et à maintenir le statut liminaire des réfugiées somaliennes au Canada et, d'autre part, sur la façon dont les Canadiennes d'origine somalienne s'y sont opposées afin de créer un sens et une place pour elles et leur famille en Amérique du Nord. Plusieurs facteurs ont eu des effets néfastes sur la santé et le bien-être des Somaliennes au Canada: les politiques et les pratiques qui les obligent à attendre de trois à cinq ans pour demander un statut de résidence permanente, les définitions eurocentriques de la famille qui restreignent les stratégies d'unification familiale de même que la marginalisation économique découlant du peu de reconnaissance de la certification étrangère.
Long ago in Somalia, we had no problems. Our problems began with the war. They killed my husband in front of me, but we go ahead with life. They're having all those problems, but still some people here think that there we didn't have electricity, water, houses, cars . . . The Canadian people think we have nothing, but we are Somalians and we are rich...-Aman, age 70, widowed, mother of nine children

$\Lambda$ $\operatorname{man}^{1}$ is one of more than seventy thousand Somali refugees who found asylum in Canada in the 1990s. ${ }^{2}$ While the numbers of Somalis admitted into Canada as Convention refugees has declined from over twelve hundred in 2000 to just over five hundred in $2002,{ }^{3}$ only an estimated 1 per cent of all Somali refugees have been resettled in a safe country. ${ }^{4}$ This paper explores the ways in which government policy and public discourse have operated to enhance and maintain the liminal status of Somali women refugees in Canada, and the ways in which Somali Canadian women have resisted these efforts in order to create meaning and a place for themselves and their families in North America. Specifically, I argue that the policies and practices that obliged many Somali women to wait three to five years to apply for permanent residency status, Eurocentric definitions of the family that constrain family unification strategies, and economic marginalization due to lack of recognition of foreign credentials have had cumulative adverse effects on the health and well-being of Somali women in Canada. Values of perseverance, mutual aid, and kinship, however, facilitate Somali women's ability to create refuge in Canada as individuals and as a community.

\section{Background}

Somalis comprise one of the largest single ethnic groups in Africa and occupy the region represented by the nationstates of Somalia and Djibouti and parts of Ethiopia and Kenya. Kinship forms the core of Somali social organization 
and segmentary lineages serve as the basis for political alliances and loyalties. Women maintain natal clan affiliation and can draw on affinal kinship networks throughout their lives. ${ }^{5}$ Islam is one of the major identifiers of Somali culture and society and has acted to unify Somalis against the potential entropy of clan divisions. Introduced to the region in the fifteenth century, Islam drew upon indigenous traditions, resulting in a syncretic form of practice and beliefs. ${ }^{6}$

Until the imposition of borders by British, Italian, and French colonial regimes, Somalis migrated throughout the Horn of Africa region. After World War II, Britain retained control over British and Italian Somaliland and parts of Ethiopia, uniting ethnic Somalis under one administration. In 1969, a military coup led by Muhammed Siyad Barre led to the establishment of the Somali Democratic Republic. Barre established himself by appealing to indigenous egalitarian ideas and Soviet aid. To develop pan-Somali identity, Barre invested in education and infrastructure, discouraged public identification of clan identity, and funded the development of the Somali orthography. His efforts to reclaim territory occupied by Somalis in the Ogaden region of Ethiopia was met with failure. The loss of the war and the effects of a subsequent drought led to unrest. ${ }^{7}$ Barre responded by consolidating power in the hands of his allies and Darood (Marehan) clan members. Opposition to the regime was solidified when the Somali Nationalist Movement was formed by members of the northern Isaaq clan. The struggles for power occurred both within and without the government and clan divisions. An estimated 350,000 people died in the civil war between 1988 and $1995 .^{8}$

\section{Somali Women}

Who can stop a Somali woman? Drown her, murder her - yes, but as long as she has breath in her body, she'll talk. ${ }^{9}$

In general, Somali gender relations and roles are inscribed by Islamic thought and practice and despite Orientalist assumptions - and fundamentalist claims - gender remains a contested rather than static issue in the history of Islam and in contemporary Somali society. Ahmed ${ }^{10}$ maintains that claims to both an egalitarian tradition in Islam and one which strictly proscribes women's behaviour originate in ethical and spiritual assertions in the Qu'ran that support the former while judicial interpretations that have in practice varied over the years have been employed to reinforce the latter. Notably, Sufism, the form of Islam most prevalent in Somalia, allowed women greater opportunity for spiritual exploration. Although Islamic ideals of virtue and honour are upheld, Somali women bear little resemblance to Orien- talist stereotypes of Islamic women as oppressed, veiled, and meek. For example, oral literature and song are engaged as expressive outlets, allowing women to voice protest and joy, describe women's conditions, encourage proper behaviour, and express solidarity. In one song, a mother sings to her daughter: "When you reach a marriageable age, and if God keeps his approval, a wicked mean and evil man, a wifebeater and intimidator, to such a man (I promise) your hand won't go." 11 Perhaps the most vivid example of the power of Somali women is found in the stories of the legendary queen Arawailo. Arawailo organized a women's strike and while the men were preoccupied with housework and childcare, she seized power. Men claim she was a cruel ruler who singled out men for her hostility while women honoured her rule. ${ }^{12}$

Traditionally, Somali men and women have been interdependent, requiring the active participation of each in Somali society and production. Nomadic women are responsible for rearing animals, weaving the mats and constructing the aqal (movable homes), caring for children, obtaining water, and selling products. In agricultural regions, women are responsible for numerous areas of production including sowing and marketing grain and caring for livestock. ${ }^{13}$ Moreover, women have been actively engaged in the independence movements, political organizations, and the civil service. ${ }^{14}$

The Barre government promoted women's participation in education and established the Somali Women's Democratic Organization; however, women's participation in decision making was limited. ${ }^{15}$ In the Somali Democratic Republic, female enrolment in elementary education increased dramatically. Life Education Centres were organized where women were trained in income generating activities often predicated on the female arts. ${ }^{16}$ In 1975, the government passed the Family Law, which declared men and women as equal, enshrining women's right to inheritance, political office, and land holdings. ${ }^{17}$ Despite these efforts, women's participation in the economy was formerly limited and women working in areas traditionally associated with men faced some resistance.

Women's sphere of activities is wide ranging and includes social, economic, and spiritual undertakings. In Somalia, women have gathered together in prayer and instruction around older women who are well versed in the Qu'ran. Particularly in urban areas, where formerly nomadic women are engaged in fewer productive activities, more time can be allotted to spiritual studies. These gatherings also contributed to the institution of the hagbad, women's lending circles, which contribute to the economic well-being of women. ${ }^{18}$ 


\section{From Somali to "Refugee"}

With the war, we left everything behind. That's all I get [holding on to her dress], my scarf, my clothes, that's all I get. All the jewelry I got were the things I had on my body. Nothing else. Some of my family died. All of my belongings were taken away — Aisha, mother of eight children

The informants' accounts of the onset of the civil war resonate with those found in other literature suggesting that the conflict and ensuing exodus from Somalia was abrupt and unanticipated. The father of acclaimed author Nuruddin Farah told his son: "We were like a horde of ants, blind with fear, and fleeing ahead of a hurricane ... Alas, we had no idea we were fleeing in the direction of the storm, not away from it." ${ }^{19}$ With little to draw on to make sense of one's circumstance, refugee experience can be disorienting - disrupting bonds of trust and familiar relations - while individuals are plunged into a process that reinforces a homogenization of identity as individuals are relegated to the category of "refugee." 20

The disruption engendered by forced migration also contributed to changes in family structure and gender roles. Many women lost family members and those who survived took on additional responsibilities and roles. For instance, in one region, 70 per cent of women surveyed reportedly cared for over ten dependents; most cared for four to five orphans. ${ }^{21}$ Moreover, women have been marginalized in refugee camps where they are also vulnerable to gender violence and sexual exploitation. ${ }^{22}$

\section{Somali Women in Canada}

I was in my home, now I'm a refugee, that's the difference. There I was like a queen, here's I'm like a chicken, like nothing.

- Aman

For most Canadians, the image of Somalia is conflated with the inquiry that drew into question the integrity of the Canadian military. The macabre photos of Shidane Arone, the ensuing cover-up of his torture and murder are foregrounded while the conflict that apparently cast Somali against Somali provided a mere rustic backdrop. In the nightly newscasts, the Somalis, if appearing at all, were portrayed as bloodthirsty or quaint. These images of a poverty-stricken, violent, and backward people, however, would not remain relegated in the public consciousness to the imaginings of eastern Africa; these people had arrived in Canada. Indeed, Canadian public discourse in the 1990s was rife with panic about immigrants who appeared at coastlines and airports threatening to drain national resources. Stories of Somali warlords entering the country and Somali women committing welfare fraud were woven into the primitivist images of Somali society contributing to an atmosphere of hostility and distrust of Somali refugees who were constituted as potentially undeserving of humanitarian compassion in Canada. ${ }^{23}$

For Somalis arriving in Canada in the 1990s, adjusting to life was complicated by the rapidity with which role changes and identities were enacted. Foremost, households headed by single women were a new phenomenon: women, therefore, were thrust into new decision-making and economic roles. ${ }^{24}$ Confronting negative stereotypes and incidences of overt racism has also been new for many Somalis, who had been accustomed to residing in a relatively homogenous environment and were now compelled to occupy diminished subject positions. Women often felt perplexed when confronting racism themselves or helpless in their ability to help their children cope with it at school where they were taunted by other students or ignored by teachers..$^{25}$ In fact, some community leaders have noted that respect for adults is eroding within the community as elders appear powerless to the younger generation in the Canadian context. ${ }^{26}$ As Ruhiyya, a divorced mother of four and community activist, remarked:

Somalis really need to learn how to deal with racism; to understand what is coming from, because we never experienced it before. A lot of women are isolated, frustrated, lack support; some have five, seven, eight kids by herself, to get to school. Do the housework, it all adds to stress. . . They are foreign to doctors, they don't know what to do ... There's a rumour that they do c-sections so they [Somali women] won't have too many kids.

\section{Canadian Policies and Somali Women}

Upon arrival in Canada, most women who arrived in the 1990s found themselves playing the "waiting game." Although they entered Canada as Convention refugees, the lack of identity documents created suspicion about their "authentic" identity. Women who came from Somalia are less likely than their male counterparts to possess a driver's license, passport, or other official documents, items which were uncommonly used in a predominantly oral society and which would have been impossible to secure following the collapse of the Somali central government. Thus where once identity was linked to family and bilateral kinship relations, now torn asunder by the conflict, the need to establish one's identity in a bureaucratic manner had become crucial to demonstrating trustworthiness and to being deserving of claiming sanctuary in Canada. The Canadian government's own analysis acknowledged that the emphasis placed on identity documentation has produced a disproportionate and negative burden 
on women. ${ }^{27}$ Eighty per cent of refugees who did not possess identity documents were women and children and in 1998 the Canadian government estimated the numbers of refugees who fell into this category to be thirteen thousand. ${ }^{28}$ Passed in 1993, Bill C-86 required refugees without official identity documents such as a passport to wait five years until they were able to apply for permanent residency status..$^{29}$ During this imposed period of liminality, women were compelled to wait to sponsor other family members whose lives may have been in peril at home or who may have been languishing in camps as part of the refugee diaspora. They had to console their children who could not attend post-secondary education because they did not qualify for "Canadian" tuition fees that are substantially lower than those offered to foreign students, nor were they eligible for student loans or bursaries. Additionally, they could not avail themselves of services that were available only to permanent residents. Regulations, therefore, stalled family reunification and integration while reinforcing the image of the Somali refugee as "welfare queen" and a drain of Canadian resources.

All we are waiting for is the work to change. We can't work; we don't have any work. All we are waiting for is the welfare cheque — Fatma, divorced, mother of five

In 1999, the waiting period was reduced to three years, despite calls from various sectors including an all-party Commons committee, to reduce the waiting period from five years to one year and to institute a system of sworn personal affidavits to affirm identities. ${ }^{30}$

In contrast, the Canadian government's response to the refugee crisis precipitated by the conflict in the former Yugoslavia differed from the programs offered Somali claimants. In response to the call by the United Nations High Commissioner for Refugees (UNHCR) for countries to step forward to provide temporary sanctuary for Kosovar refugees, the then current Minister of Citizenship and Immigration, Lucienne Robillard, announced a policy of fasttracking Kosovo refugees. Those with relatives in Canada and those deemed as having special needs were granted expedited removal from the region. Under this program, children of any age or marital status were eligible for the program and family members who were able to sponsor overseas family members could themselves be Convention refugees whereas under other circumstances only unmarried children under the age of nineteen were eligible and sponsors were required to be citizens or permanent residents. Furthermore, Kosovar refugees were granted broader health benefits than are afforded other Convention refugees and those lacking identity documents were not subject to the same waiting period to apply for permanent residency status as had been imposed on predominantly Somali and Afghani refugees who were in a similar predicament. $^{31}$

In 2001, changes to immigration policies and procedures under Bill C-11 led to the elimination of the Undocumented Protected Persons in Canada category as refugees lacking identity papers were known. Currently, an applicant must submit a statutory declaration affirming one's identity along with a similar confirmation provided by an acquaintance made prior to coming to Canada or by an official of an ethnocultural organization. ${ }^{32}$ The legislation acknowledges that refugee claimants may need to resort to forged documents to flee an untenable situation; however, it also "requires the Refugee Protection Division to take into account a claimant's lack of identity papers, inability to reasonably explain the lack of papers and failure to take reasonable steps to obtain them, when it considers the credibility of the claimant." 33

Although delays in obtaining permanent residency status demanded by these policies have been reduced over the past few years, other barriers to family reunification and integration have not been resolved. While residents and citizens may now sponsor single, dependent children under the age of twenty-two - up from the previous age limit of nineteen - the definition of family remains decidedly Eurocentric in the way in which it presumes the independence of adult children. ${ }^{34}$ As Aman explained:

Our children, even if they are at university, they live at home. Until they get married, they are with the family. It doesn't matter what age they are. The mother will cook for them, wash their clothes and take care of him, thinking, my child is at university studying. If we can, we take care of him, wash for him, feed him, and when he gets married, he's in the hands of his wife. You can raise your brother's children, your sister's children, if they need a hand, if they don't have enough economical support. They are part of your family and they keep with you. That's part of our culture.

Indeed one of the most distressing aspects of the imposed waiting period has been the concern that adult children will have outgrown the age limit for family reunification, creating sentiments shared by some mothers that they have failed their children who may be languishing in refugee camps abroad. For our respondents, caring for children, loving them, earning their love and respect brings the greatest satisfaction life can offer; therefore, reuniting with children and other family members has become the most intensive focus of women's efforts.

When the opportunity to sponsor family members is presented, other considerations come to the fore. Women them- 
selves face employment difficulties due to lack of recognition of their experience and credentials and due to their responsibility for child care and domestic responsibilities, tasks that may have been shared amongst a larger network of kin or aided by domestic workers in Somalia. Without remunerative employment, sponsoring children once they have obtained landed immigrant status is difficult. But work implies not only income, but respect and self-esteem. Safia asked:

I was a businesswoman in Mogadishu. I had my own house. We lived in our culture, in my family. Our children were respecting us, here, even if they come, how will they respect us?

Many of the informants ran successful businesses or managed enormous responsibilities as head of a large household and farm. Their stories of work, wealth, and the respect they earned contrasts with the image of Somali women as confined to oppressive households in a poor country lacking in basic amenities. Resonating with the experiences of both other groups of involuntary migrants who are cast as not only the great unwashed, but the great unskilled, and voluntary migrants, lack of recognition of credentials and work experience contribute to a downward mobility that is difficult to reverse particularly for women of colour who are generally relegated to the lowest ranks of the Canadian workforce. ${ }^{35}$

The portrayal of life in Canada contrasts with reminiscences of home that are filled with warmth, revealing a life centred around community and kin, rich in hospitality and social support where those with resources provided for those with less.

We were supporting each other. My sister was here, my mother was here, all in the same building and we were happy together. We had quite a beautiful life there. All of our country was beautiful. We were happy with what we had whether we were economically rich or not. We were happy with what we had - Fatoun

One source of distress in diasporic communities has been the inability to provide for others in the community, as individuals are hampered by few economic resources and need to remit funds to overseas kin. ${ }^{36}$ The levelling effect of the refugee experience has reduced the ability of Somalis to help one another in diaspora while at home those with resources could be counted on to assist those in need. ${ }^{37}$

\section{The Impact of Policy on Health and Well-Being}

For us, what's more important is to have our children around, to communicate and for them to love us. When I came to this country I was healthy and good enough. But now I developed high blood pressure. I'm constantly taking medicine, I'm taking too much because all my children are not here with me, also my husband. I'm thinking too much. I can't go because I don't have a landed visa. If my children are here at least, I'd feel settled and I'd feel happier where I am. I've been here five years and no documents - Safia

The cumulative effects of family disintegration, mistrust, and downward mobility may have significant health implications. In a trend that resonates with the documented loss of the healthy immigrant effect, many of the members of the Somali communities in Toronto, Ottawa, and Edmonton interviewed reported deterioration in health status. ${ }^{38}$ In particular women described a host of stress-induced conditions such as hypertension, increased cholesterol levels, cardiac problems, and type 2 diabetes that arose as a self-described consequence of uprooting and resettlement. While factors such as changes in diet and mobility undoubtedly contribute to the emergence of these ailments, continuing high levels of stress may also by themselves, or in interaction with these other determinants, create significant health implications. For instance stress induced by migration, poverty, and persecution - all of which have been experienced by the Somali women we interviewed - has been linked to type 2 diabetes as well as overall poor health status. ${ }^{39}$ Lack of social support can further exacerbate health problems. ${ }^{40}$ Importantly, stress that is ongoing and which threatens one's value systems and sense of security is believed to have the most significant health impact. ${ }^{41}$ Feelings of being mistrusted, as evidenced by the imposition of the waiting period, lack of control over work and familial environment, and the overwhelming anxiety about the safety of family members can readily be presumed to contribute to this most deleterious form of stress.

\section{Resisting the Effects of Adversity}

Somali women in Canada, however, have found myriad ways of resisting this marginalization although they, like other Moslems, have been accused of fatalism. Inshallah, if Allah wills, is the expression that frequently is heard in discussions about this process. Inshallah, I will get the papers or my family will be reunited. The term is interpreted by some as a sign of fatalism or lack of self-reliance; however, traversing the Canadian refugee process requires great determination - a rejection in fact of fatalism - and demands the ability to take action in adverse situations. I believe the term signals shared context and understanding, an invocation of empathy and support to persevere despite the uncertainties of the process refracted through the familiar currency of Islamic imagery.

Moreover, women developed other strategies to counter the adverse effects of isolation and stress on their health and 
well-being. For example, women re-established traditional loaning circles (hagbad) and formed Qur'anic study groups; often women who lacked immediate kin support turned to each other for religious study, friendship and succor. ${ }^{42}$ Women further engaged in microeconomic enterprise, from importing and selling perfumes, oils, and material from Somalia and environs to preparing foods to sell to neighbours; others advocated on behalf of the community. All of these activities are ways in which women not only added to their material well-being, but also worked to create community and to redress the impact of the policies that have circumscribed their lives in Canada. Notably, the creation of, and ability to rely on, social support has a physiological impact on the body and can reduce stress hormones and response resulting in improved health status. $^{43}$

\section{Conclusion}

Living in apartment towers, exiled to winter, images of home shared by women in these research projects suggest an opulent paradise that belies the poverty portrayed by UN statistics or the internecine struggles that have punctuated Somali political life. Visions of a rich family life are cast in a web of kin and kindness of neighbours in a portrait of a nurturing and respectful society.

Despite internal contestation, the environment was still relatively homogeneous; in Somalia, one's own language, values and religion are writ large in the greater society and are reflected back in the security of social bonds and daily life. What shatters the idyll seems to come from behind, unsuspected, vile, and swift. Little time is spent describing the hell that seemed to overrun paradise in the blink of an eye. The descriptions of women's luxurious lives in Somalia are warm and sensuous, the support of family and servants, the taste of fresh camel milk, the smell of fresh fruit; the senses and longing are heightened and contrast with hazy Ontario summer skies or the dirty slush of an Albertan spring. The recounting of these memories figures prominently as ballast against the degrading stereotypes and supplicant stance appended to the label of"refugee."

The immigration policies that pertain to voluntary migration are subject to the push and pull of global economics and geopolitics; however, refugee policies are presumed to be grounded in Canadian values and our commitment to human rights. Historically, Canadian immigration policy has been contrived as a balance between economic concerns and humanitarian commitment; however, policy making is inherently political. ${ }^{44}$ For instance, the disparity between the treatment of refugees from Somalia and those from Kosovo suggests a colour-coding of refugee policy that belies our humanitarian claims. While the elimination of the waiting period of Convention refugees without identity documents has taken effect, it has been implemented at a time when the numbers of Somalis admitted to Canada is declining. Moreover, decisions regarding the acceptability of identifications are at the discretion of a single-person panel at a time when Moslem refugees in particular are vulnerable to distrust, harassment, and detention, especially after the attacks in the US on September 11, 2001.

The imposition of a waiting period for Convention refugees lacking identity documents, impediments to family reunification, downward mobility, and economic instability have contributed to the sustained liminality experienced by Somali refugee women in Canada. These regulations have a significant impact on Somali women; they hinder not only family reunification, but the ability of Somali refugee women to integrate into Canadian society and to re-create meaningful and productive lives in the arms of their families and communities. Moreover, the policies can have deleterious health effects through the induction of chronic stress.

As refugees, the Somali women I spoke with have encountered an intransigent bureaucracy; they have learned to survive in the concrete towers of apartments that line busy streets. They have purchased snow boots and have learned to maneuver through life as single parents without the assuring support of family or the economic power to afford domestic help. Congregating when possible, forming their own Qur'anic study groups and lending circles, keeping alive the dreams of home, and finding other ways of providing and receiving support make this life possible. Resourcing social support, creating meaning, and linking the past to the present and to the future have been vital to physical, spiritual and communal survival. ${ }^{45}$

Currently, group processing of Somali and Sudanese refugees has been introduced as an innovation in the settlement process. This will enable individuals to retain bonds of kinship and friendship with the hopes of facilitating the resettlement process. ${ }^{46}$ While these initiatives emerged from the perceived need for enhanced mutual support upon arrival in Canada, refugees to Canada who have arrived here over the past decade still require attention as they have sustained the negative impact of policy on women's health. Concerted action to redress the foreign credential issue and broader definitions of the category for children would be an important start to ensure that Somali refugee women in Canada can truly participate equitably in Canadian society. 


\section{Notes}

1. This paper is informed by two qualitative studies: the first involved the collection of life stories from eleven Somali women residing in Toronto, Ottawa, and Edmonton and the second included interviews with ten women and men in Edmonton. (All names are pseudonyms.) Financial support for these projects was provided by the Isaak Walton Killam Memorial Scholarship and the Prairie Centre of Excellence for Research in Immigration and Integration. I wish to thank all of the women who shared their stories and hospitality with me. I must also express my special gratitude to Mana for her invaluable assistance, support and friendship and to Ladan for sharing her insights and writings.

2. Ladan Affi, "The Somali Crisis in Canada: The Single Mother Phenomenon," in Mending the Rips in the Sky: Options for Somali Communities in the $21^{\text {st }}$ Century, ed. H. Adam and R. Ford (Lawrenceville, NJ: Red Sea Press, 1997).

3. "Facts and Figures 2002: Immigration Overview," CIC Web site, <http://www.cic.gc.ca/english/pub/facts2002/refugee/refugee\%5F5.html> (accessed 19 April 2004).

4. Celia McMichael and Lenore Manderson, "Somali Women and Well-Being: Social Networks and Social Capital among Immigrant Women in Australia," Human Organization 63 (2004): 88-99.

5. Ioan M. Lewis, Blood and Bone: The Call of Kinship in Somali Society (Lawrenceville, NJ: Red Sea Press, 1994); Ioan M. Lewis, A Modern History of Somalia: Nation State in the Horn of Africa (Boulder: Westview Press, 1988); Edward Opoku-Dapaah, Somali Refugees in Toronto: A Profile (Toronto: York Lanes Press, 1995); Anna Simons, Networks of Dissolution: Somalia Undone (Boulder: Westview Press, 1995).

6. Mohammed Nuuh Ali, Needs Assessment of High Risk Somali Youth in the West End of Ottawa (paper prepared for PinecrestQueensway Health and Community Services, 1995).

7. Abdalla Omar Mansur, "Aspects of the Somali Tribal System," in Mending the Rips in the Sky: Options for Somali Communities in the $21^{\text {st }}$ Century, ed. H. Adam and R. Ford (Lawrenceville, NJ Red Sea Press, 1997); Ahmed I. Samatar, Socialist Somalia: Rhetoric and Reality (London: Zed Books, 1988).

8. Simons; Ali.

9. Amina Adan, "Women and Words," Ufahamu 10, no. 3 (1981), 115-42, 135.

10. OLeila Ahmed, Women and Gender in Islam (New Haven: Yale University Press, 1992.)

11. Adan, 124.

12. Ladan Affi, "Arraweelo: A Role Model for Somali Women" (presentation to the Somali Peace Culture Conference, European Association of Somali Studies, Paris, France, 25 October 1995).

13. Rhoda Ibrahim, "The Changing Lives of Somalian Women," in Changing Perceptions: Writings on Gender and Development, ed. T. Wallace and C. March (London: Oxfam, 1991); UNICEF, Women and Children in Somalia: A Situation Analysis (Mogadishu: UNICEF, 1987).
14. Ladan Affi, "Gender Integration and the Economic Role of Somali Women" (presentation to the Conference on Economic Integration and Transboundary Resources, Addis Ababa, Ethiopia, 8-11 September 1997).

15. Ibid.

16. Daphne Williams Ntiri, Female Education in Somalia: A Survey to Assess the Situation and Needs of Women, (Paris: UNESCOUNICEF-WFP Cooperative Programme, 1987).

17. UNICEF.

18. Adan.

19. Nuruddin Farah, Yesterday, Tomorrow: Voices from the Somali Diaspora (London: Cassel, 2000), 2.

20. E. Valentine Daniel and John C. Knudsen, "Introduction," in Mistrusting Refugees, ed. E. Daniel and J. Knudsen (Berkeley: University of California Press, 1995). In Yesterday, Tomorrow, Somali author Nuruddin Farah describes his first visit to a refugee camp in Kenya to meet family members who had left Somalia. An official noted that Farah's sister was "impressive" "for somebody in a refugee camp." The camp housed university professors, government officials, and various other artists and intellectuals.

21. Jane Mocellin, Psychosocial Consequences of the Somali Emergency on Women and Children: A Report to UNICEF and WHO (Winnipeg: University of Manitoba, 1993).

22. Patrick Matlou, "Upsetting the Cart: Forced Migration and Gender Issues, The African Experience," in Engendering Forced Migration: Theory and Practice, ed. D. Indra (New York: Berghan Books, 1999); Hamdi Mohammed, "Somali Refugee Women's Experiences in Kenyan Refugee Camps and Their Plight in Canada," in Mending the Rips in the Sky: Options for Somali Communities in the $21^{\text {st }}$ Century, ed. H. Adam and R. Ford (Lawrenceville, NJ: Red Sea Press, 1997).

23. Gillian Creese, "The Politics of Refugees in Canada," in Deconstructing a Nation: Immigration, Multiculturalism and Racism in '90s Canada, ed. Vic Satzewich (Halifax: Fernwood Publishing, 1992); Lisa Marie Jakubowski, Immigration and the Legalization of Racism (Halifax: Fernwood Publishing, 1997); Denise L. Spitzer, “Here, I’m Like a Chicken: Stories from Somali Women in Canada" (presentation to the Africa Society Conference, Edmonton, 27 February 1999); Mariana Valverde and Anna Pratt, "From Deserving Victims to 'Masters of Confusion': Redefining Refugees in the 1990s, Canadian Journal of Sociology 27, no. 2 (2002), 135-61; Cynthia Wright, "Nowhere at Home: Gender, Race and the Making of Anti-Immigrant Discourse in Canada, Atlantis 24, no. 2 (2000), 38-48.

24. Affi, "The Somali Crisis in Canada."

25. Denise L. Spitzer, Migration and Menopause: Women's Experience of Maturation in Three Immigrant Communities (PhD dissertation, University of Alberta, 1998); David Young, Denise L. Spitzer, and Florence Pang, "Understanding the Health Care Needs of Canadian Immigrants" (report, Prairie Centre of Excellence for Research in Immigration and Integration, Edmonton, 1999).

26. Affi, "The Somali Crisis in Canada." 
27. "Bill C-11 Immigration and Refugee Protection Act: GenderBased Analysis Chart," CIC Web site, <http://www.cic.gc. ca/english/irpa/c11-gender.html> (accessed 22 April 2004).

28. Affi, "The Somali Crisis in Canada"; "Refugees in Limbo: A Human Rights Issue" (1999), CCR Homepage, <http:// www.ccr.ca > (accessed 15 October 2000); "Refugees and Identity Documents" (1996), CCR Homepage, <http://www. ccr.ca> (accessed 15 October 2000); Rima Berns McGown, Muslims in Diaspora: The Somali Communities of London and Toronto (Toronto: University of Toronto Press, 2000).

29. Young, Spitzer, and Pang.

30. "Fact Sheet for Undocumented Convention Refugees in Canada Class (UCRCC)," CIC Web site, <http://www.cic.gc.ca /english > issued 1999 (accessed 15 October 2000).

31. "Fast Track Processing for Kosovo Refugees," CIC Web archive, <http://Web.archive.org/web/2001070115917/http:// www.cic.gc.ca/manuals/english/om-web/1999/op/op99-07. html> issued April 30, 1999 (accessed 16 April 2004).

32. "Canada's New Immigration and Refugee Protection Regulations Finalized," CIC Web site, $<$ http://www.cic.gc.ca/english/ presss/02/0218-pre.html> (accessed 28 April 2004); "Refugee Claims, Pre-Removal Risk Assessment," CIC Web site $<$ http://www.cic.gc.ca/english/irpa/faq\%2Drefugees.html> (accessed 28 April 2004). "Bill C-11 Immigration and Refugee Protection Act: Overview," CIC Web site <http://www.cic. gc. ca/english/irpa/c11-overview.html (accessed 22 April 2004).

33. Ibid.; see also "Bill C-11 Immigration and Refugee Protection Act: Gender-Based Analysis Chart," CIC Web site, <http:// www.cic.gc.ca/english/irpa/c11-gender.html $>$ (accessed 22 April 2004).

34. Ibid.

35. Ransford Danso, "From 'There' to 'Here': An Investigation of the Initial Settlement Experiences of Ethiopian and Somali Refugees in Toronto," GeoJournal 55 (2001): 3-14; Denise L. Spitzer, Anne Neufeld, and Sonia Bitar, "The Impact of Immigration Policy on Women's Health and Well-Being: A Synthesis of Workshop Findings" (Fifth International Metropolis Conference, Vancouver, B.C.; available from <http://www. pcerii.metropolis.net $>$ ); Abdolmohammed Kazemipur and Shiva Halli, "The Changing Colour of Poverty in Canada," Canadian Review of Sociology and Anthropology 38, no. 2 (2001): 217-38; Jennifer Chard, Jane Badets, and Linda Howatson-Leo, "Immigrant Women," in Women in Canada: A Gender-Based Statistical Report (Ottawa: Statistics Canada, 2000), 189-217.

36. Celia McMichael and Lenore Manderson, "Somali Women and Well-Being: Social Networks and Social Capital among Immigrant Women in Australia, Human Organization 63 (2004): 88-99; Denise L. Spitzer, Migration and Menopause: Women's Experiences of Maturation in Three Immigrant Communities (PhD dissertation, University of Alberta, 1998); Nuruddin Farah, Yesterday, Tomorrow: Voices from the Somali Diaspora (London: Cassel, 2000); Danso.

37. McMichael and Manderson; Miriam Stewart, Joan Anderson, Morton Beiser, Anne Neufeld, and Denise L. Spitzer, Multicul- tural Meanings of Social Support (report to Social Sciences and Humanities Research Council of Canada, 2003).

38. Ilene Hyman, Immigration and Health (Ottawa: Health Canada, 2001).

39. Nicola Abate and Manisha Chandalia, "The Impact of Ethnicity on Type 2 diabetes," Journal of Diabetes and Its Complications 17 (2003): 39-58; Melinda Forthofer, Nancy Janz, Julia Dodge, and Noreen Clark, "Gender Differences in the Association of Self-Esteem, Stress and Social Support with Functional Health Status among Older Adults with Heart Disease, Journal of Women \& Aging 13, no. 1 (2001), 19-37; Daniel Cox and Linda Gonder-Frederick, "Major Developments in Behavioral Diabetes Research, Journal of Consulting and Clinical Psychology 60, no. 4 (1992); 628-38.

40. Isao uk. nishi, et al., "Perception and Utilization of Social Support in Diabetic Control," Diabetes Research and Clinical Practice 41 (1998): 207-11. For discussion of social support as a determinant of health see Canada Health Action: Building on a Legacy (Ottawa: National Forum on Health, 1997).

41. Ceci Heman, Culture, Health and Illness, $2^{\text {nd }}$ ed. (Oxford: Butterworth Heinemann, 1990). These findings echo Ransford Danso's study of the settlement experiences of Somali refugees in Toronto, which found that the vast majority felt significantly demoralized. In particular, those who had been in Canada for more than ten years were least hopeful. Racism, precarious immigration status, and lack of training and education were most problematic. Lack of recognition of credentials and hence suitable employment is a major problem.

42. Neita Israelite, Arlene Herman, and Faduma Alim, "Wating for 'Sharciga': Resettlement and the Roles of Somali Refugee Women," Canadian Women's Studies 19, no. 3 (1999): 80-86.

43. A. Courtenay Devries, Erica Glasper, and Courtenay Detillion, "Social Modulation of Stress Responses," Physiology and Behavior 79 (2003): 399-407.

44. Jakubowski.

45. Daniel and Knudsen.

46. "First Group of Refugees to Be Selected under Innovative Process Arrive in Canada," CIC Web site, <http://www. cic.gc.ca/english/press/03/0349-pre.html > (accessed 19 April 2004).

Dr. Denise L. Spitzer is a medical anthropologist and the Canada Research Chair in Gender, Migration and Health at the University of Ottawa. Her work focuses on the impact of marginalization on health and well-being.

(C) Denise L. Spitzer, 2006. This open-access work is licensed under a Creative Commons Attribution-NonCommercial 4.0 International License, which permits use, reproduction and distribution in any medium for non-commercial purposes, provided the original author(s) are credited and the original publication in Refuge: Canada's Journal on Refugees is cited. 